\title{
Pengaruh Pemberian Pupuk Cair Urine Sapi terhadap Pertumbuhan dan Hasil Tanaman Mentimun (Cucumis sativus L.) pada Lahan Podsolik Merah Kuning
}

\section{(The Effect of Giving Cow Urine Liquid Fertilizer on Cucumber Growth and Yield (Cucumis sativus L.) at Red Yellow Podsolic Land)}

\author{
${ }^{1)}$ Nur Hafizah \& ${ }^{2}$ Rusmadi \\ Program Studi Agroteknologi, Sekolah Tinggi Ilmu Pertanian Amuntai \\ 1)Fifi_bjm@yahoo.co.id \\ ${ }^{2)}$ rusmadi@gmail.com
}

\begin{abstract}
ABSTRAK
Tanah podsolik merah kuning berpotensi untuk budidaya tanaman. Permasalahan yang dihadapi dalam pengembangan budidaya tanaman di lahan podsolik merah kuning yaitu pH sangat rendah dan miskin hara. Tujuan Penelitian ini adalah (i) mengetahui pengaruh pemberian pupuk cair urine sapi terhadap pertumbuhan dan hasil tanaman mentimun pada lahan podsolik merah kuning (ii) mendapatkan dosis pupuk cair urine sapi yang terbaik terhadap pertumbuhan dan hasil tanaman mentimun pada lahan podsolik merah kuning. Penelitian dilaksanakan di Desa Mantimin Kecamatan Batu Mandi Kabupaten Balangan pada bulan Juni - Juli 2011. Penelitian ini menggunakan Rancangan Acak Kelompok (RAK), dengan 5 perlakuan dan 4 ulangan, sehingga semuanya berjumlah 20 unit percobaan. Setiap satuan percobaan terdiri 4 tanaman. Faktor diuji dosis pupuk cair urin sapi, $u_{0}=0$ cc/liter air/petakan, $u_{1}=25$ cc air per petakan, $u_{2}=50 \mathrm{cc} /$ liter air/petakan, $u_{3}=75 \mathrm{cc} /$ liter air/petakan, dan $u_{4}=100 \mathrm{cc} /$ liter air/petakan. Hasil penelitian menunjukkan bahwa perlakuan dosis pupuk cair urine sapi berpengaruh nyata terhadap peubah tinggi tanaman umur 14 hari setelah tanam (HST), jumlah daun umur 14 HST, jumlah cabang pertanaman, umur tanaman saat berbunga, jumlah buah pertanaman dan berat buah pertanaman pada dosis terbaik adalah $100 \mathrm{cc} /$ liter air/petakan $\left(u_{4}\right)$ dan tidak menunjukkan pengaruh pada tinggi tanaman umur 28 HST.
\end{abstract}

Kata kunci: Podsolik, pupuk, cair, urin, sapi.

\begin{abstract}
Yellow red podsolic soil has the potential for crop cultivation. The problems faced in the development of plant cultivation on yellow red podsolic land are very low $\mathrm{pH}$ and nutrient poor. The purpose of this study was (i) to know the effect of giving cow urine liquid fertilizer to the growth and yield of cucumber plants on yellow red podsolic land (ii) to obtain the best dose of cow urine liquid fertilizer on the growth and yield of cucumber plants on red yellow podzolic fields. The study was conducted in Mantimin Village, Batu Mandi Subdistrict, Balangan Regency in June - July 2011. This study used a Randomized Block Design (RBD), with 5 treatments and 4 replications, so that all of them were 20 experimental units. Each experimental unit consists of 4 plants. Factors are tested for cow urine liquid dosage, $u_{0}=0 \mathrm{cc} /$ liter of water / plot, $u_{1}=25 \mathrm{cc}$ of water per plot, $u_{2}=50 \mathrm{cc} /$ liter of water $/$ plot, $u_{3}=$ $75 \mathrm{cc} /$ liter of water / plot, and $u_{4}=100 \mathrm{cc} /$ liter of water / plot. The results showed that the treatment of doses of cow urine fertilizer significantly affected plant height variables aged 14 days after planting (HST), number of leaves aged 14 HST, number of branches, age of plants at flowering, number of fruit crops and weight of fruit at the best dose is $100 \mathrm{cc} /$ liter of water / plot (u $\left.u_{4}\right)$ and does not show any influence on plant height at 28 HST.
\end{abstract}

Keywords : Podsolic, fertilizer, liquid, urine, cow.

\section{PENDAHULUAN}

Mentimun merupakan tumbuhan yang menghasilkan buah yang dapat dimakan. Buahnya biasanya dipanen ketika belum masak benar untuk dijadikan sayuran atau penyegar, tergantung jenisnya (Cahyono, 2006).

Kebanyakan budidaya mentimun masih dianggap usaha sampingan, sehingga rata-rata hasil mentimun secara nasional masih rendah. Padahal pengembangan 
budidaya mentimun mempunyai peranan dan sumbangan yang cukup besar terhadap peningkatan pendapatan dan taraf hidup petani, penyediaan bahan pangan bergizi bagi masyarakat luas, serta dapat diandalkan sebagai salah satu komoditas ekspor nonmigas dari sektor pertanian sub-sektor hortikultura (Rukmana, 1994).

Produksi mentimun di Indonesia masih sangat rendah yaitu 3,5 ton.ha ${ }^{-1}$ sampai 4,8 ton.ha ${ }^{-1}$. Padahal produksi mentimun hibrida dapat mencapai 20 ton.ha ${ }^{-1}$. Begitu juga untuk Kabupaten Balangan produksinya masih sangat rendah karena pada umumnya tanaman mentimun ditanam hanya sebagai tanaman selingan, hal ini terbukti dengan tidak adanya data produksi untuk budidaya mntimun untuk setiap kecamatan di Kabupaten Balangan (Dinas Pertanian Tanaman Pangan dan Hortikultura Kab. Balangan, 2010).

Luas tanah podsolik merah kuning di Kalimantan Selatan yaitu sebesar 645.077 ha dan tersebar di Kabupaten Kotabaru, Banjar, Tapin, HSS, HSU, Tanah Bumbu, dan Balangan.luas tanah podsolik merah kuning di Kabupaten Balangan adalah 72.868 ha. Kabupaten Balangan menduduki urutan ke tiga setelah Kabupaten Kotabaru 355.758 ha dan Tanah Bumbu 128.676 ha (BPN Kalsel, 2007).

Podsolik Merah Kuning (PMK) adalah jenis tanah masamyang secara alami mempunyai produktivitas rendah, didominasi oksida $\mathrm{Al}$ dan $\mathrm{Fe}$ serta daya ikat $\mathrm{P}$ yang tinggi sehingga menyebabkan ketidaktersedianya unsur $\mathrm{P}$ dalam tanah. Pupuk $\mathrm{P}$ yang diberikan akan segera membentuk senyawa yang sukar larut dengan ion-ion $\mathrm{Al}$ dan $\mathrm{Fe}$ dan terikat oleh oksida-oksida Al dan Fe sehingga sukar tersedia bagi tanaman (Buckman dan Brady, 1982).

Dari hasil analisis tanah di Desa Mantimin Kecamatan Batu Mandi sifat tanah C-Organik $1,01 \%$ kriteria sangat rendah, $\mathrm{N}$ $0,006 \%$ kriteria sangat rendah, $\mathrm{P}_{2} \mathrm{O} 54,53$ kriteria rendah, $\mathrm{K}_{2} \mathrm{O} 4,53 \%$ kriteria rendah, $\mathrm{pH} \mathrm{H}_{2} \mathrm{O} 3,91$ kriteria masam (Laboratorium Tanah FP Unlam, 2011).

Permasalahan yang dihadapi dalam pengembangan budidaya tanaman pada lahan kering podsolik merah kuning yaitu $\mathrm{pH}$ rendah, berarti kemasaman tinggi. Hal ini menyebabkan ketersediaan hara menurun, daya simpan hara makro $(\mathrm{N}, \mathrm{P}, \mathrm{K}, \mathrm{Ca}, \mathrm{Mg}$, dan $\mathrm{S}$ ), kandungan unsur mikro $\mathrm{Cu}$ juga rendah (Notohadiprawiro, 2006).

Di masa sekarang ini banyak orang yang menggunakan pupuk anorganik. Pupuk kimia apabila digunakan terus menerus menjadi tidak efisien dan dapat mengganggu keseimbangan sifat tanah sehingga menurunkan produktifitaslahan dan mempengaruhi produksi. Oleh karena itu kita harus mengubahnya pola penggunaan pupuk anorganik, halini disebabkan karena pupuk anorganik meninggalkan residu kimia (Lingga, 2007).

Pupuk organik mempunyai efek jangka panjang yang baik bagi tanah, yaitu dapat memperbaiki struktur kandungan organik tanah dan juga menghasilkan produk pertanian yang aman bagi kesehatan. Salah satu contoh pupuk organik adalah pupuk kompos dan pupuk cair (Lingga, 2007).

Salah satu bahan dasar pembuat pupuk organik cair adalah urine sapi perah. Sejak dahulu kala, daging, kulit, serta kotoran sapi memang termasuk komoditi yang telah terbukti mempunyainilai ekonomis yang tinggi. Kini urine sapi ternyata telah mulai menjadi komoditi berharga yaitu sebagai pupuk cair organik (Wibisono, 2010).

Pupuk cair urine sapi terbukti cukup baik sebagai penyubur tanaman, selain sebagai penyubur, pupuk ini juga ada berkhasiat untuk menghalau hama. Dengan demikian, penggunaan pupuk cair organik dari urine sapi ini dapat menambah keuntungan para petani, karena mengurangi biaya operasional perawatan tanaman (Naswir, 2003). Tujuan Penelitian ini adalah (i) mengetahui pengaruh pemberian pupuk cair urine sapi terhadap pertumbuhan dan hasil tanaman mentimun pada lahan podsolik merah kuning (ii) Mendapatkan dosis pupuk cair urine sapi yang terbaik terhadap pertumbuhan dan hasil tanaman mentimun pada lahan podsolik merah kuning.

METODE PENELITIAN 
Penelitian dilaksanakan di Desa Mantimin Kecamatan Batu Mandi Kabupaten Balangan pada bulan Juni - Juli 2011. Rancangan percobaan menggunakan faktor tunggal yaitu dosis pupuk cair urine sapi (U) yang terdiri dari lima taraf perlakuan, sedangkan rancangan lingkungan yang digunakan adalah Rancangan Acak Kelompok (RAK) berulangan empat, dimana pengelompokan berdasarkan distribusi cahaya matahari, sehingga semuanya berjumlah 20 unit percobaan. Faktor dosis pupuk cair urine sapi $(\mathrm{u})$ terdiri dari lima taraf yaitu $\mathrm{u}_{0}\left(0 \mathrm{cc} / \mathrm{liter}\right.$ air/petakan; $\mathrm{u}_{1}(25 \mathrm{cc} / \mathrm{liter}$ air/petakan; $\mathrm{u}_{2}(50 \mathrm{cc} /$ liter air/petakan $) ; \mathrm{u}_{3}(75$ cc/liter air/petakan $) ; \quad u_{4} \quad(100 \quad$ cc/liter air/petakan). Tiap satuan percobaan diambil empat tanaman sebagai sampel. Pelaksanaan penelitian terdiri dari tahap persiapan, pelaksanaan, pemeliharaan pemanenan dan pengamatan. Pengamatan dilakukan terhadap tinggi tanaman, jumlah daun, jumlah cabang, umur saat berbunga pertama, jumlah buah per tanaman dan berat buah per tanaman.

\section{HASIL DAN PEMBAHASAN}

\section{Hasil}

\section{Tinggi Tanaman}

Dari hasil pengukuran tinggi tanaman pada umur 14, 21 dan 28 HST dan hasil analisis sidik ragamnya menunjukan bahwa dosis pupuk cair urine sapi berpengaruh sangat nyata terhadap tinggi tanaman pada umur 14 HST dan berpengaruh nyata terhadap tinggi tanaman umur 21 HST. Sedangkan tinggi tanaman pada umur 28 HST tidak berpengaruh.

Tabel 1. Rata-rata tinggi tanaman mentimun umur 14, dan 21 HST

\begin{tabular}{ccc}
\hline \multirow{2}{*}{ Perlakuan } & \multicolumn{2}{c}{ Rata-rata jumlah daun (helai) } \\
\cline { 2 - 3 } & $14 \mathrm{HST}$ & $21 \mathrm{HST}$ \\
\hline $\mathrm{u}_{0}$ & $8,3125^{\mathrm{a}}$ & $44,25^{\mathrm{a}}$ \\
$\mathrm{u}_{1}$ & $11,625^{\mathrm{b}}$ & $52,75^{\mathrm{bc}}$ \\
$\mathrm{u}_{2}$ & $11,1875^{\mathrm{b}}$ & $51,56^{\mathrm{b}}$ \\
$\mathrm{u}_{3}$ & $11,0625^{\mathrm{b}}$ & $54,62^{\mathrm{c}}$ \\
$\mathrm{u}_{4}$ & $14,25^{\mathrm{c}}$ & $66^{\mathrm{b}}$ \\
\hline
\end{tabular}

Keterangan : Nilai rerata yang diikuti huruf superscrift yang sama pada kolom yang sama menunjukan perlakuan tersebut tidak berbeda nyata berdasarkan uji DMRT pada taraf $5 \%$.

Dari Tabel 1 terlihat bahwa tinggi tanaman pada umur 14 HST pemberian pupuk cair urine sapi dengan dosis $0 \mathrm{cc}$ per liter air per petakan berbeda nyata dengan dosis 25,50 , 75 dan $100 \mathrm{cc}$ per liter air per petakan. Perlakuan pada dosis 25, 50 dan 75 cc per liter air per petakan jika dibandingkan tidak menunjukkan perbedaan yang nyata. Pemberian pupuk cair urine sapi dengan dosis $100 \mathrm{cc}$ per liter air per petakan berbeda nyata dengan dosis $0,25,50$ dan 75 cc per liter air per petakan

\section{Jumlah Daun}

Dari hasil penghitungan jumlah daun pada umur 14, 21 dan 28 HST dan hasil analisis sidik ragamnya, menunjukan bahwa dosis pupuk cair urine sapi berpengaruh sangat nyata terhadap jumlah daun pada umur 14 HST dan berpengaruh nyata terhadap jumlah daun umur 21 dan 28 HST. Rerata jumlah daun disajikan pada Tabel 1. 
Tabel 1. Rata-rata jumlah daun mentimun umur 14, 21 dan 28 HST

\begin{tabular}{cccc}
\hline \multirow{2}{*}{ Perlakuan } & \multicolumn{3}{c}{ Rata-rata jumlah daun (helai) } \\
\cline { 2 - 4 } & $14 \mathrm{HST}$ & $21 \mathrm{HST}$ & $28 \mathrm{HST}$ \\
\hline $\mathrm{u}_{0}$ & $2^{\mathrm{a}}$ & $4,5625^{\mathrm{a}}$ & $11,5^{\mathrm{a}}$ \\
$\mathrm{u}_{1}$ & $3,0625^{\mathrm{b}}$ & $5,875^{\mathrm{ab}}$ & $15^{\mathrm{ab}}$ \\
$\mathrm{u}_{2}$ & $3,3125^{\mathrm{b}}$ & $5,5^{\mathrm{a}}$ & $18,06^{\mathrm{b}}$ \\
$\mathrm{u}_{3}$ & $3,4375^{\mathrm{bc}}$ & $5,875^{\mathrm{ab}}$ & $11,62^{\mathrm{b}}$ \\
$\mathrm{u}_{4}$ & $3,875^{\mathrm{c}}$ & $7,125^{\mathrm{b}}$ & $21,31^{\mathrm{c}}$ \\
\hline
\end{tabular}

Keterangan : Nilai rerata yang diikuti huruf superscrift yang sama pada kolom yang sama menunjukan perlakuan tersebut tidak berbeda nyata berdasarkan uji DMRT pada taraf $5 \%$.

Dari Tabel 1 terlihat bahwa jumlah daun pada umur 14 HST pemberian pupuk cair urine sapi dengan dosis 0 cc per liter airper petakan berbeda dengan dosis 25,50 , 75 dan $100 \mathrm{cc} /$ liter air/petakan. Perlakuan pada dosis 25,50 dan $75 \mathrm{cc} /$ liter air/petakan jika dibandingkan tidak menunjukan perbedaan yang nyata. Pemberian pupuk cair urine sapi dengan dosis $100 \mathrm{cc}$ per lter air per petakan berbeda dengan dosis $0,25,50$ dan $75 \mathrm{cc} /$ liter air/petakan.

Pada umur 21 HST pemberian pupuk cair urine sapi dengan dosis $0 \mathrm{cc}$ per lter air per petakan tidak berbeda dengan dosis 50 cc/liter air/petakan, tetapi berbeda dengan dengan dosis $100 \mathrm{cc}$ per lter air per petakan. Perlakuan pada dosis 0, 25, 50 dan 75 cc/liter air/petakan jika dibandingkan tidak menunjukan perbedaan yang nyata.
Pada umur 28 HST pemberian pupuk cair urine sapi dengan dosis $0 \mathrm{cc}$ per lter air per petakan berbeda nyata dengan dosis 25 , 50, 75 dan $100 \mathrm{cc} /$ liter air/petakan. Perlakuan pada dosis 25, 50, 75 dan 100 cc/liter air/petakan jika dibandingkan tidak menunjukan perbedaan yang nyata.

Dari data tersebut maka perlakuan dois terbaik untuk jumlah daun pada umur 14, 21 dan 28 HST didapatkan pada dosis 100 cc/liter air/petakan.

\section{Jumlah Cabang Pertanaman}

Dari hasil penghitungan jumlah cabang pada saat panen terakhir dan hasil analisis sidik ragamnya menunjukan bahwa dosis pupuk cair urine sapi berpengaruh sangat nyata terhadap jumlah cabang pertanaman pada saat panen terakhir. Rerata jumlah cabang disajikan pada Tabel 2 .

Tabel 2. Rata-rata jumlah cabang pertanaman mentimun

\begin{tabular}{c|c}
\hline Perlakuan & Rata-rata jumlah cabang pertanaman \\
\hline $\mathrm{u}_{0}$ & $1^{\mathrm{a}}$ \\
$\mathrm{u}_{1}$ & $1,625^{\mathrm{b}}$ \\
$\mathrm{u}_{2}$ & $1,9375^{\mathrm{b}}$ \\
$\mathrm{u}_{3}$ & $2,5625^{\mathrm{c}}$ \\
$\mathrm{u}_{4}$ & $3,375^{\mathrm{d}}$ \\
\hline
\end{tabular}

Keterangan : Nilai rerata yang diikuti huruf superscrift yang sama pada kolom yang sama menunjukan perlakuan tersebut tidak berbeda nyata berdasarkan uji DMRT pada taraf $5 \%$.

Dari Tabel 2 terlihat bahwa jumlah cabang pertanaman pemberian pupuk cair urine sapi dengan dosis $0 \mathrm{cc} /$ liter air/petakan berbeda nyata dengan dosis $25,50,75$ dan $100 \mathrm{cc} /$ liter air/petakan. Perlakuan pada dosis 25 dan 50 cc/liter air/petakan jika dibandingkan tidak menunjukan perbedaan yang nyata. Pemberian pupuk cair urine sapi dengan dosis $100 \mathrm{cc} /$ liter air/petakan berbeda nyata dengan dosis $0,25,50$ dan 75 cc/liter air/petakan. Dari data tersebut maka perlakuan dosis terbaik untuk jumlah cabang pertanaman pada saat panen terakhir 
Nur Hafizah \& Rusmadi, Pengaruh pemberian pupuk cair urine...

didapatkan pada dosis 100 cc/liter air/petakan.

\section{Umur Tanaman Saat Berbunga}

Dari hasil penghitungan umur tanaman saat berbunga dan hasil analisis sidik ragamnya, menunjukan bahwa dosis pupuk cair urine sapi berpengaruh sangat nyata terhadap umur tanaman saat berbunga. Rerata umur tanaman saat berbunga disajikan pada Tabel 3.

Tabel 3. Rata-rata umur tanaman saat berbunga pada tanaman mentimun

\begin{tabular}{c|c}
\hline Perlakuan & Rata-rata umur tanaman mulai berbunga \\
\hline $\mathrm{u}_{0}$ & $30,6875^{\mathrm{a}}$ \\
$\mathrm{u}_{1}$ & $28,9375^{\mathrm{b}}$ \\
$\mathrm{u}_{2}$ & $28,8125^{\mathrm{b}}$ \\
$\mathrm{u}_{3}$ & $28,625^{\mathrm{b}}$ \\
$\mathrm{u}_{4}$ & $27,0625^{\mathrm{c}}$ \\
\hline
\end{tabular}

.Keterangan : Nilai rerata yang diikuti huruf superscrift yang sama pada kolom yang sama menunjukan perlakuan tersebut tidak berbeda nyata berdasarkan uji DMRT pada taraf $5 \%$.

Dari Tabel 3 terlihat bahwa umur tanaman saat berbunga pertama pemberian pupuk cair urine sapi dengan dosis $0 \mathrm{cc} / \mathrm{liter}$ air/petakan berbeda nyata dengan dosis 25 , 50, 75 dan $100 \mathrm{cc} /$ liter air/petakan. Perlakuan pada dosis 25,50 dan 75 cc/liter air/petakan jika dibandingkan tidak menunjukan perbedaan yang nyata. Pemberian pupuk cair urine sapi dengan dosis 100 cc/liter air/petakan berbeda nyata dengan dosis 0,25 , 50 dan $75 \mathrm{cc} /$ liter air/petakan. Dari data tersebut maka perlakuan dois terbaik untuk umur tanaman saat berbunga pertama didapatkan pada dosis 100 cc/liter air/petakan.

\section{Jumlah Buah Pertanaman}

Dari hasil perhitungan jumlah buah pertanaman menunjukan bahwa dosis pupuk cair urine sapi berpengaruh sangat nyata terhadap jumlah buah pertanaman. Rerata jumlah buah pertanaman disajikan pada Tabel 4.

Tabel 4. Rata-rata jumlah buah pertanaman mentimun

\begin{tabular}{c|c}
\hline Perlakuan & Rata-rata jumlah buah pertanaman \\
\hline $\mathrm{u}_{0}$ & $1,8525^{\mathrm{a}}$ \\
$\mathrm{u}_{1}$ & $2,3725^{\mathrm{b}}$ \\
$\mathrm{u}_{2}$ & $2,6850^{\mathrm{c}}$ \\
$\mathrm{u}_{3}$ & $2,8100^{\mathrm{c}}$ \\
$\mathrm{u}_{4}$ & $3,2275^{\mathrm{d}}$ \\
\hline
\end{tabular}

Keterangan : Nilai rerata yang diikuti huruf superscrift yang sama pada kolom yang sama menunjukan perlakuan tersebut tidak berbeda nyata berdasarkan uji DMRT pada taraf $5 \%$.

Dari Tabel 4 terlihat bahwa pada pengamatan jumlah buah pertanaman pemberian pupuk cair urine sapi dengan dosis 0 cc/liter air/petakan berbeda nyata dengan dosis 25, 50, 75 dan $100 \mathrm{cc} /$ liter air/petakan. Perlakuan pada dosis 50 dan 75 cc/liter air/petakan jika dibandingkan tidak menunjukan perbedaan yang nyata.
Pemberian pupuk cair urine sapi dengan dosis $100 \mathrm{cc}$ per lter air per petakan berbeda nyata dengan dosis $0,25,50$ dan 75 cc/liter air/petakan. dosis terbaik untuk jumlah buah pertanaman didapatkan pada dosis 100 cc/liter air/petakan.

\section{Berat Buah Pertanaman}


Dari hasil penghitungan berat buah pertanaman dan hasil analisis sidik ragamnya menunjukan bahwa dosis pupuk cair urine sapi berpengaruh sangat nyata terhadap berat buah pertanaman. Rerata berat buah pertanaman disajikan pada Tabel 5.

Tabel 5. Rata-rata berat buah pertanaman pada tanaman mentimun

\begin{tabular}{c|c}
\hline Perlakuan & Rata-rata berat buah pertanaman \\
\hline $\mathrm{u}_{0}$ & $683,25^{\mathrm{a}}$ \\
$\mathrm{u}_{1}$ & $1199,5^{\mathrm{b}}$ \\
$\mathrm{u}_{2}$ & $1449,75^{\mathrm{b}}$ \\
$\mathrm{u}_{3}$ & $1566,5^{\mathrm{b}}$ \\
$\mathrm{u}_{4}$ & $1941,25^{\mathrm{c}}$ \\
\hline
\end{tabular}

Keterangan : Nilai rerata yang diikuti huruf superscrift yang sama pada kolom yang sama menunjukan perlakuan tersebut tidak berbeda nyata berdasarkan uji DMRT pada taraf $5 \%$.

Dari Tabel 5 terlihat bahwa pengamatan berat buah pertanaman pemberian pupuk cair urine sapi dengan dosis $0 \mathrm{cc} /$ liter air/petakan berbeda nyata dengan dosis 25, 50, 75 dan $100 \mathrm{cc} /$ liter air/petakan. Perlakuan pada dosis 25, 50 dan 75 cc/liter air/petakan jika dibandingkan tidak menunjukan perbedaan yang nyata. Pemberian pupuk cair urine sapi dengan dosis $100 \mathrm{cc} /$ liter air/petakan berbeda nyata dengan dosis 0, 25, 50 dan $75 \mathrm{cc} /$ liter air/petakan. Dari data tersebut maka perlakuan dois terbaik untuk berat buah pertanaman didapatkan pada dosis 100 cc/liter air/petakan.

\section{Pembahasan}

Berdasarkan hasil penelitian memperlihatkan perlakuan pemberian dosis pupuk cair urine sapi menunjukan pengaruh yang sangat nyata hamper pada semua peubah tanaman yang diamati. Hal ini berarti pemberian pupuk cair urine sapi memberikan pengaruh yang positif terhadap pertumbuhan dan hasil tanaman mentimun. Diduga karena pupuk cair urine sapi merk Elang yang digunakan dalam penelitian ini mengandung unsur $\mathrm{N}, \mathrm{P}, \mathrm{K}, \mathrm{Ca}$ dan unsur hara mikro seperti fe, $\mathrm{Mn}, \mathrm{Zn}$, Co dan $\mathrm{Cu}$ yang sangat diperlukan dalam pertumbuhan dan perkembangan tumbuhan. Menurut Sutrisno (1989), bahwa dengan pemberian unsur hara dalam jumlah yang cukup akan memberikan pertumbuhan yang normal pada tanaman. Dengan pertumbuhan yang normal maka akan meninhkatkan potensi genetik tanaman seperti bentuk, ukuran, dan berat buah yang dihasilkan.

Berdasarkan hasil analisis ragam terlihat bahwa pemberian pupuk cair urine sapi menunjukan bahwa pengaruh sangat nyata terhadap tinggi tanaman pada umur 14 HST dan berpengaruh nyata terhadap tinggi tanaman umur 21 HST, tetapi tidak berpengaruh nyata terhadap tinggi tanaman umur 28 HST. Dari hasil uji beda niali tengah terlihat bahwa hasil tertinggi pada perlakuan $\left(\mu_{4}\right)$ dosis $100 \mathrm{cc} /$ liter air/petakan dan hasil ini berbeda nyata terhadap perlakuan lain terutama denagn control $\left(\mu_{0}\right) \quad 0 \quad$ cc/liter air/petakan. Diduga bahwa pada saat fase pertumbuhan vegetative tanaman, ketersediaan unsur hara yang terdapat pada pupuk cair urine sapi memenuhi untuk perttumbuhan mentimun sehingga unsur0unsur tersebut dapat diserap dengan baik oleh tanaman, khususnya unsur Nitrogen $(\mathrm{N})$ yang banyak terkandung pada pupuk cair urine sapi. Hal ini sesuai denagn pernyataan Lingga dan Marsono (2007) yang menyatakan bahwa peranan utama dari Nitrogen adalah untuk merangsang petumbuhan secara keseluruhan bagiantanaman khususnya batang, cabang dan daun tanaman.

Kandungan $\mathrm{N}$ pada urine sapi mempengaruhi dua arah pertumbuhan tanaman yaitu vegetative dan generative. Untuk tanaman dengan tipe pertumbuhan dan perkembangan ndeterminet atau pertumbuhan vegetatif yang terus 
berlangsung, penambahan urine sapi sampai batas tertentu dapat mengaktifkan proses pemanjangan, pembesaran dan pembelahan sel pada tunas-tunas apical pada tanaman mentimun (Prihmantoro, 1996).

Pemberian pupuk cair urine sapi tidak berpengaruh terhadap tinggi tanaman pada umur 28 HST. Hal ini diduga karena tanaman mentimun sedang mengalami pertumbuhan generatif sehingga tidak menunjukan pengaruh yang nyata terhadap tinggi tanaman umur 28 HST.

Menurut Suharno (2010), tahap vegetatif tanaman berlangsung mulai dari perkecambahan biji sampai inisiasi, sedangkan tahap reproduksi (generatif) tanaman dimulai dari inisiasi (permulaan pembentukan bunga) sampai buah yang dihasilkan masak penuh.

Pemberian pupuk cair urine sapi berpengaruh sangat nyata terhadap jumlah daun pada umur 14 HST dan berpengaruh nyata terhadap jumlah daun umur 21 dan 28 HST. Dari hasil uji beda nilai tengah terlihat bahwa hasil tertinggi pada perlakuan $\left(\mathrm{u}_{4}\right)$ dosis 100 cc/liter air/petakan. Dan berdasarkan analisis ragam pada jumlah cabang pada saat panen terakhir menunjukan bahwa berpengaruh sangat nyata terhadap jumlah cabang pertanaman. Dari hasil uji beda niali tengah terlihat bahwa hasil tertinggi untuk pengamatan jumlah cabang adalah pada perlakuan $\left(\mathrm{u}_{4}\right)$ dosis $100 \mathrm{cc} / \mathrm{liter}$ air/petakan.

Diduga bahwa penambahan jumlah daun dan jumlah cabang banyak memerlukan unsur-unsur hara yang terkandung dalam pupuk cair urine sapi merk Elang seperti unsur hara makro dan mikro. Menurut Lingga (2007), bahwa nitrogen mempunyai peran penting dalam merangsang pertumbuhan sepertibatang, cabang, daun, dan akar serta sangat penting dalam pembentukan protein, lemak dan senyawa-senyawa lain.

Pada fase vegetatif tanaman, seluruh proses fisiologis hanya ditujukan untuk pembentukan daun, cabang dan anakan. Pada fase vegetative ini diperlukan banyak pupuk nitrogen (Suharno, 2010). Selain unsur hara makro yang terdapat pada pupuk cair urinesapi, unsur hara mikro jug tak kalah penting dalam proses perbanyakan daun dan cabang. Hal ini sesuai dengan pendapat Abdi (2009) yang menyatakan bahwa fungsi Mn pada pertumbuhan adalah pada proses fotolisis air (penguraian air) sehingga terbentik energi yang dapat digunakan tanaman untuk proses-proses metabolism sepoerti absorbs, transpirasi, pembelahan sel, pembungaan, pembentukan nuah dan lainlain. Dan menurut Lakitan (2004), unsur Zn yangterdapat pada pupuk cair urine sapi berpartisipasi dalam pembentukan klorofil dan pencegahan kerusakan molekul klorofil, beberapa enzim juga hanya dapat berfungsi jika terdapat unsur seng ( $\mathrm{Zn}$ ) yang terikat kuat pada molekul enzim tersebut.

Pemberian dosis pupuk cair urine sapi berpengaruh sangat nyata terhadap umur tanman saat berbunga pertama, jumlah buah pertanaman dan berat buah pertanaman. Hal ini diduga karena pupuk cair urine sapi mampu memberikan ketersediaan unsur hara yang cukup bagi pertumbuhan generatif tanaman.

Penelitian ini menunjukan bahwa pemberian dosis terbaik terhadap peubah umur tanaman saat berbunga pertama, jumlah buah pertanaman dan berat buah pertanaman ditunjukan pada dosis $100 \mathrm{cc} / \mathrm{liter}$ air/petakan $\left(\mathrm{u}_{4}\right)$, hal ini diduga karena ketersediaan unsur hara bagi pertumbuhan generatif tanamanmencapai titik optimal pada dosis tersebut.

Adanya pengaruh yang sangat nyata dari pemberian pupuk cair urine sapi apabila dibandingkan dengan tanpa penggunaan pupuk cair urine sapi $\left(\mathrm{u}_{0}\right)$, hal ini diduga karena pengaruh unsur $\mathrm{P}$ dan adanya zat perangsang tumbuh yaitu auksin yang terdapat pada pupuk cair urine sapi. Menurut Lingga dan Marsono (2007), unsur P diperlukan untruk tanamn memperbanyak pertumbuhan generatif (bunga dan buah) sehingga kekurangan unsur $\mathrm{P}$ dapat menyebabkan produksi tanaman menjadi menurun.

Menurut Nazwir (2003), fungsi zat perangsang tumbuh auksin pada tanaman antara lain merangsang pertumbuahndan mempertinggi persentase timbulnya bunga dan buah, mendorong partenokarpi yaitu kondisi dimana tanaman berbuah tanpa fertilisasi atau penyerbukan, megurangi 
gugurnya bauh sebelum waktunya, serta mematahkan dominasi pucuk atau apical yaitu suatu kondisi diaman pucuk tanaman dan akar tidak mau berkembang. Heddy (1999) menambahkan bahwa, auksin IAA (Indole Acetic Acid) dengan rumus $\mathrm{C}_{10} \mathrm{H}_{9} \mathrm{O}_{2} \mathrm{~N}$ dapat mempengaruhi masa vegetative dan generatif pada tanaman, mempunyai peranan terhadap pembelahan sel, pembesaran sel dan diferesiasi sel.

Pada perlakuan $\mathrm{u}_{0}$ terlihat beberapa tanaman terserang hama dan penyakit, pada daun terlihat bercak-bercak dan adanya lubang-lubang bekas gigitan ulat. Walaupun tidak sampai merusak keseluruhan tanaman mentimun, tetapi hali ini dapat mengganggu pertumbuhannya. Hal ini diduga karena pada perlakuan $\mathrm{u}_{0}$ tanaman kekurangan unsur hara $\mathrm{P}$ yang menyebabkan tanamn gampang terserang penyakit. Menurut Makarim et. al., (1995) bahwa unsur $\mathrm{P}$ berperan dalam mempercepat pembentukan buah, bunga dan biji, memperbaiki kualitas tanamn serta meningkatkan daya tahan terhadap penyakit. Raharja (2005) menambahkan bahwa, pemupukan urine sapi akan mengandung unsur $\mathrm{N}, \mathrm{P}, \mathrm{K}$ yang lebih tinggi dan mengandung $\mathrm{Ca}$ yang dapat meningkatkan terhadap serangan hama dan penyakit.

\section{KESIMPULAN}

Perlakuan dosis pupuk cair urine sapi berpengaruh nyata terhadap peubah tinggi tanaman umur 14 HST, jumlah daun umur 14 HST, jumlah cabang pertanaman, umur tanaman saat berbunga, jumlah buah pertanaman dan berat buah pertanaman. Berpengaruh nyata terhadap peubah tinggi tanaman umur $21 \mathrm{HST}$, jumlah daun umur 21 dan 28 HST serta tidak menunjukan pengaruh pada tinggi tanaman umur 28 HST. Perlakuan dosis pupuk cair urine sapi 100 cc/liter air/petakan ( $\left.\mathrm{u}_{4}\right)$ merupakan dosis terbaik terhadap pertumbuhan vegetatif dan pertumbuhan generatif tanaman mentimun pada semua peubah yang diamati.

\section{DAFTAR PUSTAKA}

Abdi, 2009. Pentingnya Menjaga Keseimbangan Unsur Hara Makro dan
Mikro
untuk
Tanaman.
http://www.tanindo.com
Diakses
tanggal 24 Juli 2011.

Badan Pertanahan Nasional Provinsi Kalsel. 2007. Luas Wilayah Menurut Jenis Tanah. http://tanah bumbukab.bps.go.id. Diakses tanggal 15 April 2011.

Badan Pertanahan Nasional RI. 2010. Luas Wilayah Menurut Jenis Tanah Di Indonesia. http://bps.go.id. Diakses Tanggal 15 April 2011.

Buckman, H.O dan Nyle C.B. 1982. Ilmu Tanah. Bhratara Karya Aksara. Jakarta.

Cahyono, H. 2006. Teknik Budidaya Tanaman Timun. Aneka Ilmu. Semarang.

Dinas Pangan dan Hortikultura. 2010. Laporan Tahunan Dinas Pertanian. Dinas Pertanian Tanaman Pangan dan Hortikultura Kabupaten Balangan. Paringin.

Heddy, S. 1999. Hormon Tumbuhan. Rajawali. Jakarta.

Laboratorium Tanah FP Unlam. 2011. Hasil analisis tanah Desa Mantimin Kecamatan Batu Mandi Kabupaten Balangan. Banjarbaru.

Lakitan, B. 2004. Dasar-Dasar Fisiologi Tumbuhan. PT Raja Grafindo Persada. Jakarta.

Lingga, P. dan Marsono. 2007. Petunjuk Penggunaan Pupuk. Penebar Swadaya. Jakarta.

Makarim, A., E, Suhartatik dan A, Kartoharjono. 1995. Silicon Hara Penting Tanaman Padi. http://www.kimialipi.net/index.Diakses tanggal 24 Juli 2011. 
Nur Hafizah \& Rusmadi, Pengaruh pemberian pupuk cair urine...

Nazwir. 2003. Pemanfaatan Urine Sapi Yang

Dipermentasi sebagai Nutrisi

Tanaman.http://soil.faperta.ugm.ac.i

d. Diakses tanggal 06 Mei 2011.

Notohadiprawiro. 2006. Ilmu Tanah.

Universitas Gadjah Mada.

Yogyakarta.

Prihmantoro, H. 1996. Memupuk Tanaman

Sayur. Penebar Swadaya. Jakarta.

Raharja, A. 2005. Pupuk dan Pestisida. http://www.tanindo.com. Diakses tanggal 24 Juli 2011.

Rukmana, R. 1994. Budidaya Mentimun.

Kanisius. Yogyakarta.

Suharno. 2010. Mata Kuliah serealia. http://www,distan.pmda-diy.go.id. Diakses tanggal 3 Juli 2011.

Warsito. 1978. Sayuran Buah. C.V. Bhakti Wiyata Putera. Jakarta.

Wibisono, A. W. 2010. Pupuk Cair Urine Sapi. http://duniasapi.com. Diakses tanggal 06 Mei 2011. 